\section{Working around the}

\section{big academy in the Soviet Union}

\section{London}

Several new scientific organizations have emerged in the Soviet Union in the past few weeks, at least some of them from discontent with the Academy of Sciences. In May, for example, a group of physicists established the Moscow Physical Society, which they consider to be the spiritual heir of the Russian Physical Society, dissolved by Stalin in 1931.

By organizing conferences and publishing two journals, one specialist, one more general, the society hopes not only to facilitate publication of papers by physicists generally, but also to provide a wider forum for the discussion of matters of public interest. The establishment of the society, the founders note, has ended the anomaly by which the Soviet Union shared with Albania the doubtful distinction of being the only "developed" country without a physical society.

Another anomaly was formally remedied last month with the establishment of the "Russian People's Academy of Sciences". Since the late 1920s, academies on that pattern have been regarded as one of the hallmarks of the sovereignty of the union republics which constitute the Soviet Union.

Yet the largest republic of all, the Russian SFSR, has never had its own academy, although, by an administrative quirk, the Siberian Branch of the AllUnion Academy of Sciences is financed from the Russian and not the All-Union budget. Proposals for a separate Russian Academy have been in the air for the past two years, partly as a reaction to the growing ethnic consciousness of the nonRussian republics and under the influence of patriotic Russian scholars such as Academician Dmitrii Likhachev, one of the leading activists in the campaign against the diversion of the Siberian rivers.

Yet another manifestation of Soviet scientists' desire to organize outside the academy network is the new Scientists' Trade Union, the formation of which was announced in Moscow News last month. But the official academy may not be as hidebound as its critics imply. Its monthly Vestnik has, in recent issues, displayed a remarkable degree of glasnost. The April issue, in particular, began with a dose of self-criticism, saying that it had failed to be a "tribune for discussion" and promising in future to keep its readers informed on important projects undertaken by the academy and of the progress of science overseas. To match the change of policy, 18 out of 21 members of the editorial board have been sacked. Vera Rich

\title{
Remains returned to tribe
}

\section{Washington}

AFTER several years of agonizing, Stanford University decided two weeks ago to return its collection of Native American skeletal remains to the Ohlone tribe of northern California, who want to rebury them in accordance with ancestral traditions. The Stanford decision marks the first time such a wholesale return of remains has been accepted by an academic body. But the university's good intentions are already getting it into trouble; ownership of the bones is being contested by the archaeologist who found them in the $1960 \mathrm{~s}$.

Bert Gerow, professor emeritus of anthropology at Stanford, says he and his students found most of the bones at two sites in the San Francisco Bay area, and dates them at from a few hundred to a few thousand years old. During that period, says Gerow, there is evidence from the bones and other gravesite artefacts that Ohlone use of the sites supplanted previous occupancy by unrelated Indian groups. He disputes the Ohlones' right of possession.

The Smithsonian Institution in Washington is the biggest institution to have faced the general problem of ownership of archaeological remains. It has a collection of about 18,000 bones from across the country, and maintains a policy of returning skeletal remains of named individuals to identifiable descendants, but such decisions can be made only for bones disintered comparatively recently. In 1988 , the Smithsonian returned to the Blackfeet of Montana a set of bones which, it was proved, had been disinterred from a known gravesite in 1892 by collectors working for the Army Medical Museum.

But most of the Smithsonian's possessions are prehistoric, dating from a time when many groups of Native Americans, especially those of the midwestern and northern plains states, were peripatetic, if not nomadic. Only with the European conquest, and the enforced confinement of groups of Indians to particular areas, did the modern tribal system evolve. For the most part, an association of ancient remains with modern descendants cannot even in principle be made.

In fact, what little is known about the migration and evolution of the early inhabitants of North America has been discovered largely through archaeological investigation, and this has led in some cases to co-operation between scientists and Native Americans who are trying to trace the history and culture of their people. Some more immediate benefits are also claimed: Native Americans suffer from a high incidence of rheumatoid arthritis and osteoporosis, and research on bones may help explain why. But the same resurgence of interest by Native
Americans in their past, which motivates much of the archaeological research, has also increased sensitivity to the treatment of human remains.

There have been efforts in Congress to provide legal guidelines for the disposition of Indian American remains, but they are moving slowly. Beyond the practical difficulties of deciding who owns what, different tribal groups have their own ideas of what constitutes proper treatment. Whereas the Ohlones seem pleased to take the bones from two historical sites in their entirety, the Blackfeet, who got some remains back from the Smithsonian last year, went to great lengths to be assured that what they received were truly their own; having alien remains in a Blackfoot grave would be as irreligious as having Blackfoot remains in the museum.

The Stanford case adds a new twist to battles over the ownership of bones. Gerow says that the Stanford bones have no direct connection with the modern Ohlone people, and belong to him.

Stanford University, on the other hand, has decided that, in this case at least, scientific interest is outweighed by the sentimental if not directly demonstrable link between the Ohlones and their forefathers. But the settlement between the university and the Ohlone tribe, hailed by both sides as an amicable resolution of a delicate dispute, now seems destined to become a squabble in a legal no-man'sland where the university's regulations provide no guidance.

David Lindley

\section{ERYTHROPOEITIN}

\section{Government to pay}

\section{Washington}

DesPITE initial fears that Amgen's newly approved erythropoietin (EPO), see Nature 339,$493 ; 1989$ ) would be too expensive for government reimbursement schemes, the US Health Care Financing Administration has announced that it will pay for the drug for kidney-dialysis patients. The agency will pay $\$ 40$ for each administration, on top of the dialysis costs that it pays for all dialysis patients in the United States.

Amgen's partner in the development of EPO, Johnson \& Johnson, announced last week that its Ortho Pharmaceutical division will give the drug free to AIDS patients, under a special pre-approval programme called a treatment IND. J\&J has licensed the non-dialysis EPO market from Amgen, and is seeking US Food and Drug Administration (FDA) approval for using it to treat anaemias of any cause. The treatment IND designation was designed by FDA to allow access to drugs before approval to patients with life-threatening diseases. 